\title{
Bizarre endothelial reaction: histological mimicry of epithelial malignancy in gastric endoscopic biopsy
}

\author{
Andleeb Abrari, Urmi Mukherjee, Rajesh Tandon, M Chandrashekhar, Poonam Das, Bhavna Bansal \\ Department of Histopathology, Max Super Specialty Hospital, New Delhi, India
}

Correspondence to Andleeb Abrari, abrariand@gmail.com

\section{DESCRIPTION}

Gastric endoscopic biopsies often reveal pseudoneoplastic processes which can be misinterpreted as malignant by the unwary. ${ }^{12}$

In this case the lamina propria of the non-ulcerated gastric mucosa was densely infiltrated by epithelioid cells with significant cytological abnormalities. There was marked non-uniform karyomegaly, with irregular nuclear contours and frequent macronucleoli in the infiltrating cells. Some of these cells showed intracytoplasmic lumen formation strongly suggesting poorly differentiated signet ring cell carcinoma (figure 1).
However, careful scrutiny by microscope revealed red blood cells in a rare intracellular lumen and the immunoprofile (vimentin, CD 34 and factor VIII related antigen positive and pan-cytokeratin, CD68 and epithelial membrane antigen negative) confirmed the reactive mesenchymalendothelial origin of these cells (figure 2 ). ${ }^{3}$

Competing interests None.

Patient consent Not obtained.

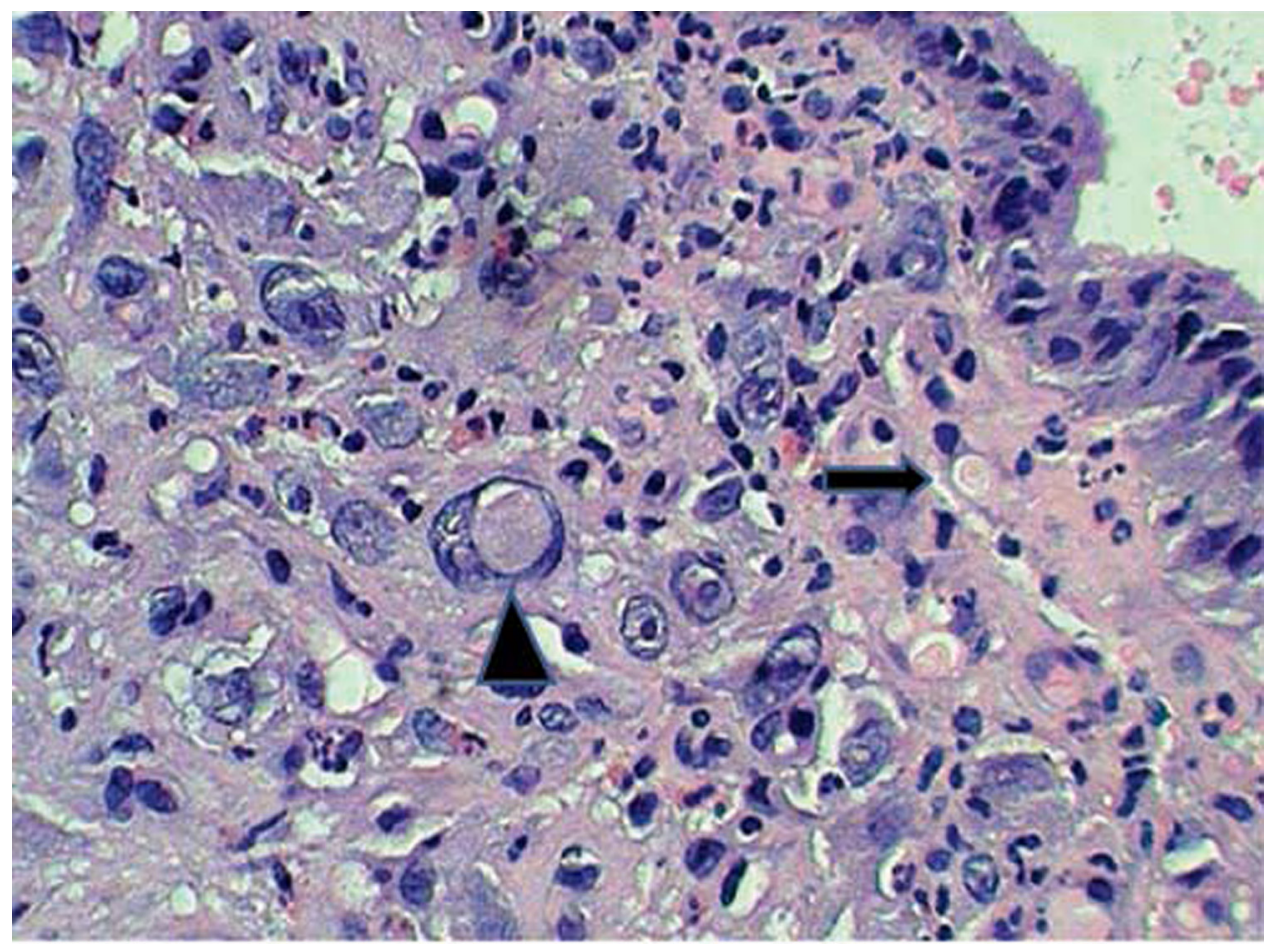

Figure 1 Lamina propria infiltration by highly atypical epithelioid cells, some of which have intracytoplasmic lumens. A red blood cell is seen within one of these lumens (arrow), while the strange cell in the centre of the field shows a fibrin plug (arrowhead). 


\section{BMJ Case Reports}

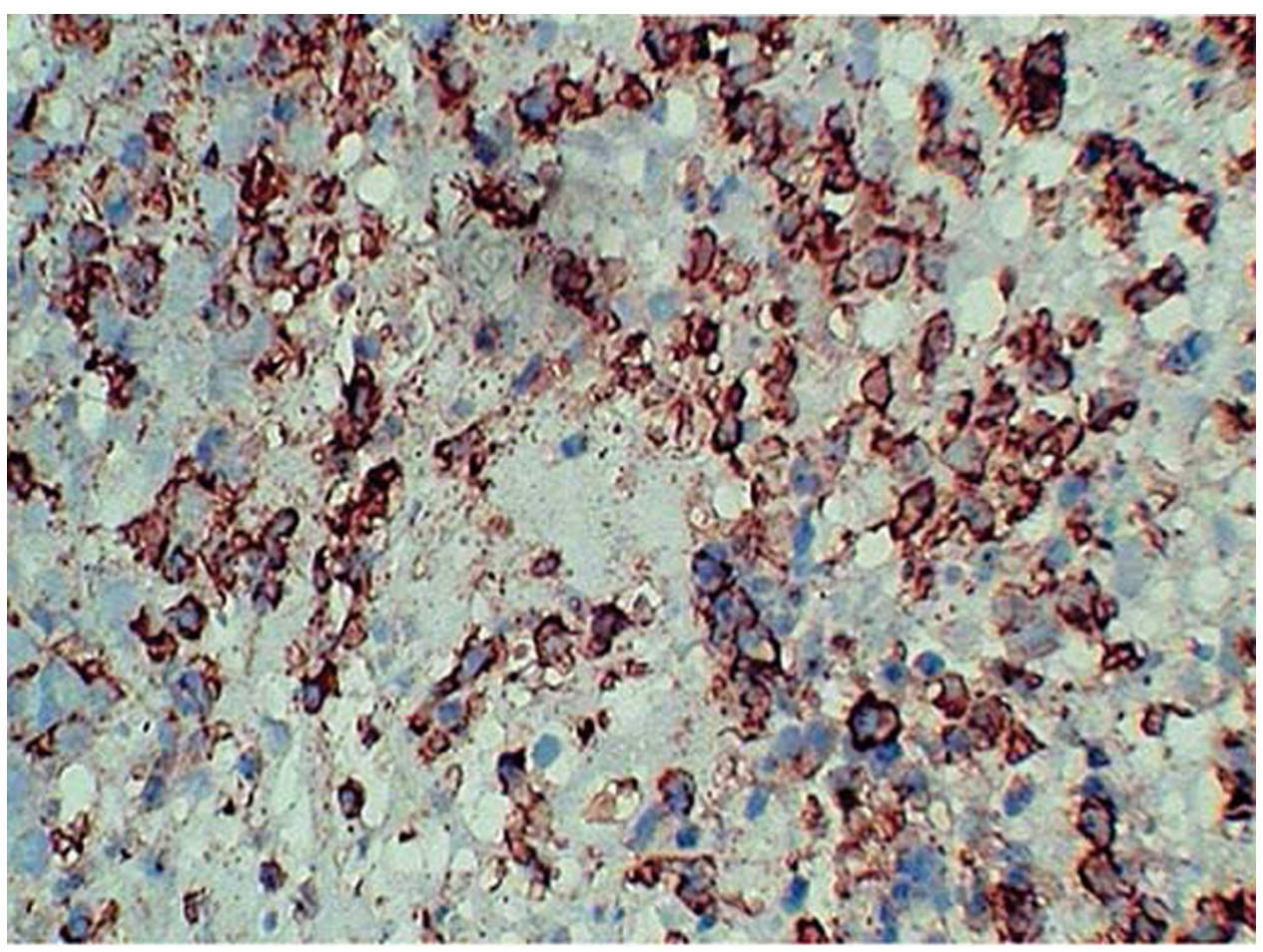

Figure 2 Atypical cells marked with von Willebrand Factor (factor VIII related antigen) on immunohistochemistry.

\section{REFERENCES}

1. Fitzgibbons PL. Pseudoneoplastic lesions of the alimentary tract. In: Wick MR, Humphrey PA, Ritter JH, eds. Pathology of Pseudoneoplastic Lesions.

Philadelphia, PA: Lippincott-Raven 1997:131-157.
2. Houghton $\mathbf{0}$, Herron B. Benign signet ring cells in the subserosa of the smal intestine: a pseudoneoplastic phenomenon. U/ster Med J 2006;75(1):93-4.

3. Petris GD, Leung ST. Pseudoneoplasms of the gastrointestinal tract. Arch Pathol Lab Med 2010;134:378-92.

This pdf has been created automatically from the final edited text and images

Copyright 2010 BMJ Publishing Group. All rights reserved. For permission to reuse any of this content visit

http://group.bmi.com/group/rights-licensing/permissions.

BMJ Case Report Fellows may re-use this article for personal use and teaching without any further permission.

Please cite this article as follows (you will need to access the article online to obtain the date of publication)

Abrari A, Mukherjee U, Tandon R, Chandrashekhar M, Das P, Bansal B. Bizarre endothelial reaction: histological mimicry of epithelial malignancy in gastric endoscopic biopsy. BMJ Case Reports 2010;10.1136/bcr.10.2010.3433, date of publication

Become a Fellow of BMJ Case Reports today and you can:

- Submit as many cases as you like

- Enjoy fast sympathetic peer review and rapid publication of accepted articles

- Access all the published articles

Re-use any of the published material for personal use and teaching without further permission

For information on Institutional Fellowships contact consortiasales@bmjgroup.com

Visit casereports.bmj.com for more articles like this and to become a Fellow 